(1)

\title{
Adiponectin in mice with altered GH action: links to insulin sensitivity and longevity?
}

\author{
Ellen R Lubbers ${ }^{1}$, Edward O List ${ }^{1}$, Adam Jara ${ }^{1,2}$, Lucila Sackman-Sala', \\ Jose Cordoba-Chacon ${ }^{4}$, Manuel D Gahete ${ }^{4}$, Rhonda D Kineman ${ }^{4}$, Ravneet Boparai ${ }^{5}$, \\ Andrzej Bartke $^{5}$, John J Kopchick ${ }^{1,2}$ and Darlene E Berryman ${ }^{1,2,3}$ \\ ${ }^{1}$ Edison Biotechnology Institute, ${ }^{2}$ Department of Biomedical Sciences, College of Osteopathic Medicine and ${ }^{3}$ School \\ of Applied Health Sciences and Wellness, College of Health Sciences and Professions, E338 Grover Center, Ohio \\ University, Athens, Ohio 45701, USA \\ ${ }^{4}$ Jesse Brown VA Medical Center, Research and Development, Chicago, Illinois 60612, USA \\ ${ }^{5}$ Southern Illinois University School of Medicine, Springfield, Illinois 62794, USA
}

\author{
Correspondence \\ should be addressed to \\ D E Berryman \\ Email \\ berrymad@ohio.edu
}

\begin{abstract}
Adiponectin is positively correlated with longevity and negatively correlated with many obesity-related diseases. While there are several circulating forms of adiponectin, the high-molecular-weight (HMW) version has been suggested to have the predominant bioactivity. Adiponectin gene expression and cognate serum protein levels are of particular interest in mice with altered GH signaling as these mice exhibit extremes in obesity that are positively associated with insulin sensitivity and lifespan as opposed to the typical negative association of these factors. While a few studies have reported total adiponectin levels in young adult mice with altered $\mathrm{GH}$ signaling, much remains unresolved, including changes in adiponectin levels with advancing age, proportion of total adiponectin in the HMW form, adipose depot of origin, and differential effects of GH vs IGF1. Therefore, the purpose of this study was to address these issues using assorted mouse lines with altered GH signaling. Our results show that adiponectin is generally negatively associated with GH activity, regardless of age. Further, the amount of HMW adiponectin is consistently linked with the level of total adiponectin and not necessarily with previously reported lifespan or insulin sensitivity of these mice. Interestingly, circulating adiponectin levels correlated strongly with inguinal fat mass, implying that the effects of $\mathrm{GH}$ on adiponectin are depot specific. Interestingly, rbGH, but not IGF1, decreased circulating total and HMW adiponectin levels. Taken together, these results fill important gaps in the literature related to $\mathrm{GH}$ and adiponectin and question the frequently reported associations of total and HMW adiponectin with insulin sensitivity and longevity.
\end{abstract}

Key Words

- adiponectin

- high molecular weight adiponectin

- growth hormone receptor

- growth hormone

- growth hormone deficiency

- growth hormone antagonist

\section{Introduction}

Adipose tissue, once considered a simple triglyceride storage organ, is now known as an active endocrine organ, which releases many adipokines. The most abundant adipokine synthesized and secreted from white adipose tissue (WAT) is adiponectin (Maeda et al. 1996). In humans, adiponectin has been shown to decrease in 
concentration as fat mass increases, unlike most other adipokines (Arita et al. 1999, Kern et al. 2003). Thus, adiponectin is considered a beneficial adipokine, showing negative correlations with many age- and obesity-related diseases and a positive correlation with longevity and insulin sensitivity (McKee Alderman et al. 2010, Arai et al. 2011). Adiponectin has also been linked to healthy phenotypes in mice, as adiponectin injections have been shown to reverse or decrease insulin resistance in several obesity prone mouse lines (Berg et al. 2001, Yamauchi et al. 2001). Further, increased adiponectin levels are associated with extended longevity in mice. That is, transgenic mice expressing high levels of human adiponectin have increased longevity (Otabe et al. 2007), and various mice with extended longevity have increased adiponectin (Flurkey et al. 2001, Combs et al. 2003, Berryman et al. 2004, Wang et al. 2006, 2007, Arumugam et al. 2007, del Rincon et al. 2007, Alderman et al. 2009, Qiao et al. 2011).

Adiponectin is of particular interest in mice with altered GH action, as these animals exhibit alterations in obesity, insulin sensitivity, and lifespan that break the typical patterns; that is, mice with increased GH signaling tend to be lean, insulin resistant, and shortlived, while mice with low GH signaling tend to be obese, insulin sensitive, and long-lived (Coschigano et al. 2000, 2003, Berryman et al. 2004, 2011, Liu et al. 2004, Olsson et al. 2005, List et al. 2009). Previous studies have shown that adult $\mathrm{GH}$ receptor $\left(\mathrm{Ghr}^{-/-}\right)$knockout mice, which have essentially no GH signaling, and GH antagonist (GHA) transgenic mice, which have a reduction in GH signaling, have increased circulating total adiponectin (Berryman et al. 2004, Nilsson et al. 2005, Laron \& Kopchick 2011, Masternak et al. 2012). Other mouse strains with decreased GH signaling, such as Ames dwarf, Snell dwarf, Lit/Lit, and Sma1 mice, also have elevated total adiponectin levels (Flurkey et al. 2001, Combs et al. 2003, Berryman et al. 2004, Wang et al. 2006, 2007, Arumugam et al. 2007, del Rincon et al. 2007, Alderman et al. 2009). By contrast, bGH transgenic mice have an increase in GH signaling and a decrease in circulating total adiponectin (Berryman et al. 2004, Nilsson et al. 2005, del Rincon et al. 2007, Wang et al. 2007). These mouse models of altered GH action have human clinical analogs. $\mathrm{Ghr}^{-/-}$mice are analogous to humans affected by Laron syndrome, who have a mutation in the GH receptor (Laron \& Kopchick 2011). Like $\mathrm{Ghr}^{-/-}$mice, individuals with Laron syndrome have increased adiponectin (Kanety et al. 2009). Similarly, bGH transgenic mice are larger than controls with high serum levels of insulin-like growth factor 1 (IGF1) and are comparable to untreated human acromegalic individuals (Olsson et al. 2005). As in bGH mice, adiponectin levels in individuals with acromegaly are decreased (Lam et al. 2004).

There are several unresolved issues related to adiponectin in mice with altered GH action. First, $\mathrm{Ghr}^{-/-}$, GHA, and bGH mice exhibit major changes in the amount of WAT with advancing age, which may influence adipokine secretion over time (Coschigano et al. 2000, 2003, Bartke 2003, Magon 2009, Palmer et al. 2009, Berryman et al. 2010, List et al. 2011). Secondly, little is known about the relative secretory contribution of individual WAT depots to circulating adiponectin in these mice that are known to have preferential accumulation of fat in specific depots. Thirdly, no previous studies on mice with altered GH action have differentiated between the total and high-molecular-weight (HMW) forms of adiponectin. As the HMW form is considered to have the predominant bioactivity in terms of insulin sensitivity (Pajvani et al. 2004, Fisher et al. 2005, Hara et al. 2006, Kadowaki et al. 2006, Lara-Castro et al. 2006, Trujillo \& Scherer 2006, von Eynatten et al. 2008, Wang et al. 2008), studies that have assessed only total adiponectin levels may be misleading as they do not reflect the abundance of the more bioactive form. Finally, measurement of adiponectin levels in other mouse models that have more moderate alterations in the GH axis would support the link between GH action and circulating adiponectin levels. Thus, the current study includes several additional models: HiGH mice, which have a moderate (two- to threefold) increase in circulating GH; AOiGHD mice, which have adult-onset isolated GH deficiency; and Ames dwarf mice, which are deficient in GH, TSH, and prolactin (Masternak et al. 2010, Gahete et al. 2011, Luque et al. 2011). Additionally, inclusion of mice injected with GH or IGF1 allows us to determine the differential effects of $\mathrm{GH}$ and IGF1 on circulating adiponectin. Therefore, the major goals of this study were to determine the circulating levels of total and HMW adiponectin throughout life in bGH, GHA, and $\mathrm{Ghr}^{-/-}$mice, evaluate circulating adiponectin in other mouse lines with altered $\mathrm{GH}$ action, determine the depot of origin of normal and increased circulating adiponectin, examine the effects of acute GH exposure to genetically normal mice that have not been chronically exposed to altered GH levels, and establish differential effects of GH and IGF1 on circulating adiponectin.

Published by Bioscientifica Ltd. 


\section{Materials and methods}

\section{Animals and sample collection}

bGH, GHA, and Ghr ${ }^{-/-}$mice For the majority of experiments, three genetically modified animal models were used: $\mathrm{GH}$ receptor knockout $\left(G h r^{-/-}\right)$mice, GHA mice, and bGH transgenic mice, all of which have been previously described (Chen et al. 1991, Zhou et al. 1997, Berryman et al. 2004). These three mouse strains were either produced on a pure C57BL/6J background or backcrossed more than ten generations into C57BL/6J mice. These animals were bred and housed up to four animals per cage at the Ohio University animal facility with a $10 \mathrm{~h}$ light:14 h darkness cycle. After weaning, mice had ad libitum access to standard rodent chow (ProLab RMH 3000, PMI Nutrition International, Inc., St Louis, MO, USA) throughout the study. Animals were fasted for 12 h overnight before whole blood collection from the tail tip using heparinized capillary tubes. Blood was centrifuged at $4000 \mathrm{~g}$ for $10 \mathrm{~min}$ at $4{ }^{\circ} \mathrm{C}$ to separate and isolate plasma, which was stored at $-80^{\circ} \mathrm{C}$ until time of analysis. Tissue samples were dissected after killing by cervical dislocation, flash-frozen in liquid nitrogen, and stored at $-80{ }^{\circ} \mathrm{C}$ until further processing. Animal protocols for these mice were approved by Ohio University's Institutional Animal Care and Use Committee.

Administration of GH and IGF1 C57BL/6J mice were purchased from The Jackson Laboratory at 4 weeks of age and put onto a high-fat (HF) diet (D12492; Research Diets, New Brunswick, NJ, USA). Based on previous studies, it is known that adiposity differences in chow-fed $\mathrm{GH}$-injected mice are minimal, while effects of $\mathrm{GH}$ injection on body composition are more robust in HFfed mice (List 2010, Ding et al. 2011). Additionally, the changes in circulating adiponectin caused by the relatively short-term exposure to GH/IGF1 in injected mice are expected to be less dramatic than the changes seen in mice with genetic modulations in the $\mathrm{GH}$ axis. Thus, to make potential differences in adipokine levels between groups more apparent, this study used HF-fed mice for GH and IGF1 injections. Mice were kept on a HF diet for 16 weeks and housed two to three per cage with a $10 \mathrm{~h}$ light: $14 \mathrm{~h}$ darkness cycle. Purified rbGH, a gift from Monsanto (St Louis, MO, USA), and rhIGF1, a gift from Tercica, Inc. (Brisbane, CA, USA), were diluted in PBS. At 5 months of age, mice were injected s.c. twice daily with $5.0 \mu \mathrm{g} \mathrm{rbGH} / \mathrm{g}$ body weight, $2.5 \mu \mathrm{g} \mathrm{IGF1/g} \mathrm{body} \mathrm{weight,} \mathrm{or} \mathrm{both} \mathrm{for}$ 3 weeks. Whole blood was collected through ocular bleeding after a 12-h overnight fast. Plasma was isolated as described earlier. GH and IGF1 injection studies were conducted at Ohio University and were approved by Ohio University's IACUC.

HiGH and AOiGHD mice Mice with elevated endogenous GH levels (referred to as HiGH mice; Gahete et al. 2011) show a selective knockout of both the Insr and IgfIr only in the GH-producing cells of the anterior pituitary, which results in a threefold increase in circulating GH levels, a $20 \%$ increase in circulating IGF1, and a modest (10\%) increase in body weight compared with controls. Floxed mice served as controls. AOiGHD mice (Luque et al. 2011) have a selective destruction of the Cre-inducible diphtheria toxin receptor (iDTR) expressing GH-producing cells of the anterior pituitary following treatment with diphtheria toxin (DT) at 12 weeks of age, which leads to a 60 and $20 \%$ reduction in circulating GH and IGF1 levels respectively. DT-treated iDTR mice, not expressing the rGHpCre transgene, served as controls. Both $\mathrm{HiGH}$ and AOiGHD mice were created on a C57BL/6 background.

$\mathrm{HiGH}$ mice, AOiGHD mice, and their respective controls were housed two to four mice per cage with a $12 \mathrm{~h}$ light: $12 \mathrm{~h}$ darkness cycle. Mice were weaned onto standard rodent chow (Formulab Diet, Purina Mills, Inc., Richmond, IN, USA). Based on previous studies, it is known that HiGH and AOiGHD mice show few phenotypic differences from controls when fed a low-fat diet. Thus, to make potential differences between groups more apparent, at 12 weeks of age, mice were switched to a HF diet (HF-fat, \#12492; Research Diets). Ad libitum access to food and water was allowed throughout the study. At 6.5 months of age, mice were killed by decapitation and trunk blood and tissues were collected under fed conditions. The HiGH and AOiGHD studies were conducted at the Jesse Brown VA Medical Center (JBVAMC; Chicago, IL, USA) with the approval of the JBVAMC and University of Illinois at Chicago IACUC.

Ames dwarf mice Ames dwarf mice (Prop $1^{d f} /$ Prop $1^{d f}$ ) and normal $\left(+/+\right.$ or $+/$ Prop $\left.1^{d f}\right)$ littermate controls were produced on a heterozygous genetic background and housed four to five per cage with a $12 \mathrm{~h}$ light: $12 \mathrm{~h}$ darkness cycle. To date, there is no evidence that heterozygous animals for Ames dwarfism differ from WT animals. Mice were fed a standard chow ad libitum (Rodent Laboratory Chow 5001; LabDiet, PMI Feeds, Inc., St Louis, MO, USA). At 6 months of age, fasted whole blood was collected via cardiac puncture following isoflurane administration at Southern Illinois University. Animal protocols for these

Published by Bioscientifica Ltd. 
mice were approved by the Southern Illinois University Animal Care and Use Committee.

\section{Body composition}

A quantitative NMR machine was used to analyze body composition within 1 week of blood collection in bGH, GHA, and $\mathrm{Ghr}^{-/-}$mice (Minispec, Bruker Optics, Billerica, MA, USA or Echo MRI whole-body composition analyzer; Echo Medical Systems, Houston, TX, USA).

\section{Leptin and insulin levels}

Leptin was quantified using the Quantikine Mouse Leptin Immunoassay distributed by R\&D Systems (Minneapolis, MN, USA; catalog number SMOBO0). Insulin was quantified using the Mouse Insulin ELISA distributed by ALPCO Diagnostics (Salem, NH, USA; catalog number 80-INSMS-E10). The intra-assay and interassay coefficients of variation $(\mathrm{CV})$ were 5.3 and $7.2 \%$ respectively for insulin and 4.3 and $7.8 \%$ for leptin.

\section{Total and HMW adiponectin in serum or plasma}

HMW and total adiponectin were quantified using the Adiponectin (mouse) HMW and Total ELISA manufactured by Sekisui Medical Company (Ibaraki, Japan) and distributed by ALPCO Diagnostics (Salem, NH, USA; catalog number 47-ADPMS-E01) (Ebinuma \& Matsuo 2009). Both total and HMW adiponectin are quantified on the same plate alongside a single standard curve. Total adiponectin, which includes HMW (12-mer and 18-mer), MMW (hexamer), and LMW (trimer and albumin-bound trimer), was measured without any modification to their respective structures. HMW adiponectin is measured following pretreatment of samples with a specific protease that digests hexameric and trimeric adiponectin multimers. All samples were analyzed in duplicate. Tests were performed to verify that increased lipid in the serum or plasma did not interfere with the accuracy of the assay (data not shown). The intra-assay and interassay CV were 2.7 and $3.5 \%$ respectively.

\section{Tissue adiponectin protein content}

Approximately $50 \mathrm{mg}$ WAT from 6-month-old $\mathrm{Ghr}^{-/-}$and WT mice were homogenized in $150 \mu$ PBS using a probe sonicator. Samples were centrifuged at $5000 \boldsymbol{g}$ and the fat cake was removed from the remaining homogenate. Homogenates were stored at $-80^{\circ} \mathrm{C}$ until analysis with a
Table 1 Primers for mouse Adipoq and reference genes used for quantitative real-time PCR. All primers are listed $3^{\prime}-5^{\prime}$

\begin{tabular}{|c|c|c|c|}
\hline Gene & Forward primer & Reverse primer & $\begin{array}{l}\text { Product } \\
\text { length }(b p)\end{array}$ \\
\hline Adipoq & $\begin{array}{l}\text { СТCTCCTGTTCCTCT- } \\
\text { TAATCCT }\end{array}$ & $\begin{array}{l}\text { ACCAAGAA- } \\
\text { GACCTGCATCTC }\end{array}$ & 218 \\
\hline Rps3 & $\begin{array}{l}\text { ATCAGAGAGTT- } \\
\text { GACCGCAGTT }\end{array}$ & $\begin{array}{l}\text { AATGAACCGAAG- } \\
\text { CACACCATA }\end{array}$ & 183 \\
\hline$B 2 m$ & $\begin{array}{l}\text { CTGGTCTTTCTA- } \\
\text { TATCCTGGCT }\end{array}$ & $\begin{array}{l}\text { CATGTCTCGATCC- } \\
\text { CAGTAGAC }\end{array}$ & 121 \\
\hline
\end{tabular}

Quantikine Mouse Adiponectin/Acrp30 Immunoassay (R\&D Systems; catalog number MRP300). Total protein content of the tissues was measured using the Bio-Rad Protein Assay, following the manufacturer's specifications (Bio-Rad; catalog number 500-0006).

\section{RNA isolation and real-time PCR}

RNA was isolated from inguinal and epididymal WAT from 2-month-old bGH, 12-month-old $\mathrm{Ghr}^{-/-}$, and 18-monthold GHA mice and their WT littermate controls using TRIzol Reagent following the manufacturer's protocol (Life Technologies; catalog number 15596-026). Sample selection was based on mouse availability and varying lifespan of these animals. cDNA was synthesized using Maxima First-Strand cDNA Synthesis Kits and quantitative real-time PCR was performed using Maxima SYBR Green/Fluorescein qPCR Master Mix (Thermo Scientific, Waltham, MA, USA). Adipoq expression in WAT was normalized to beta 2 microglobulin (B2m) and ribosomal protein S3 (Rps3). In our laboratory, these housekeeping genes have been determined to be the most stable among nine housekeeping genes for WAT (Xinyue Wang, unpublished results). The sequences of the primers used are shown in Table 1 . Analysis of all qPCR data was performed with Biogazelle qbasePLUS (Biogazelle NV, Zwijnaarde, Belgium).

\section{Statistical analysis}

All data are represented as mean \pm s.E.M. A multivariate two-way ANOVA with Tukey's honestly significant difference post hoc test (SPSS 17.0, IBM SPSS Statistics, Somers, NY, USA) was used to identify differences among groups. Follow-up $t$-tests and one-way ANOVAs were used to determine specific genotype or tissue differences. Pearson correlations were used to analyze the relationship between insulin, leptin, tissue weights, or body composition and circulating adiponectin levels. Differences were considered significant at $P<0.05$.

Published by Bioscientifica Ltd. 


\section{Results}

\section{Circulating HMW and total adiponectin in GHA, $\mathrm{Ghr}^{-/-}$, and bGH mice}

Circulating concentrations of adiponectin (HMW and total) were measured at several time points for bGH, $G h r^{-/-}$, and GHA mice and their controls, providing a life-long profile (Fig. 1A, B, C, D, E and F). For bGH animals, 2-, 6-, 9-, and 14-month-old mice were used; for GHA, 3.2-, 6-, 12-, and 16.5-month-old mice were used; and for $G h r^{-/-}$, 6-, 12-, and 24-month-old mice were used. Sample selection was based on mouse availability and varying lifespan of these animals.

The life-long total adiponectin profile shows that circulating levels of total adiponectin were increased in $G h r^{-/-}$and GHA mice compared with WT controls at every time point (Fig. 1B and C). In GHA mice, total adiponectin increased over life, reaching levels comparable to $G h r^{-/-}$ mice by 1 year of age. Total adiponectin was significantly decreased in bGH mice compared with WT at most ages, but at 14 months of age, the difference between bGH and WT mice was no longer significant (Fig. 1A).

HMW adiponectin has not been previously reported at any age in bGH, GHA, or $G h r^{-/-}$mice. Circulating total and HMW adiponectin levels were reported previously for 12- and 24-month-old WT mice (Sackmann-Sala et al. $2012 a, b)$. Like total adiponectin, circulating HMW adiponectin was increased in $G h r^{-/-}$mice compared with WT controls at all time points (Fig. 1F). HMW adiponectin was also increased in GHA mice compared with WT at 3.2, 12, and 16.5 months, but the increase was not significant at 6 months of age (Fig. 1E). In bGH mice, HMW adiponectin was significantly decreased in 2-month-old mice compared with WT, but there was no significant difference at older ages (Fig. 1D).

The ratio of HMW to total adiponectin has been suggested to be a valuable way to report HMW adiponectin findings, as it reflects the preferential change in HMW adiponectin production, rather than a change in all MW forms (Waki et al. 2003). The ratio of HMW to total
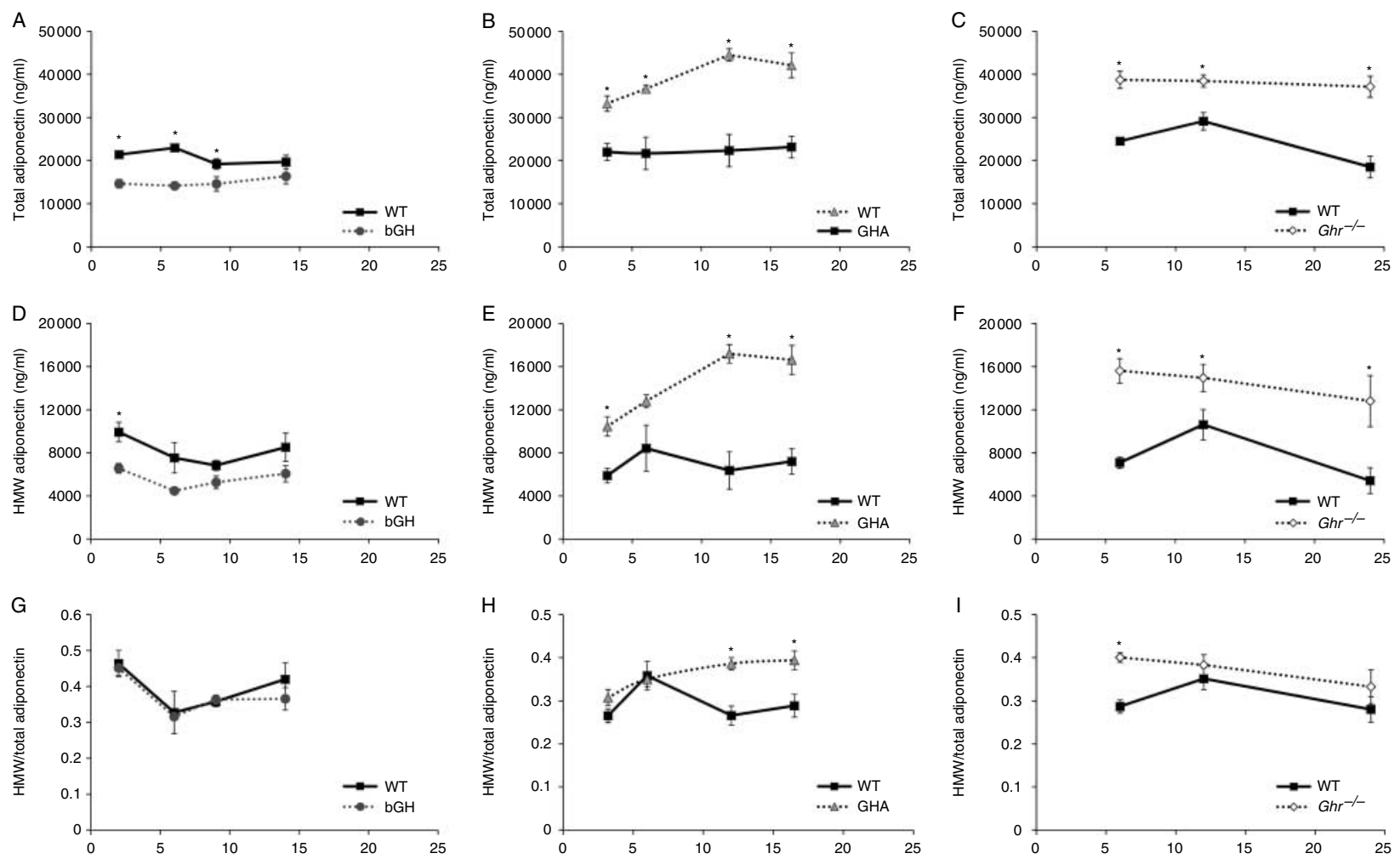

Figure 1

Circulating total adiponectin, HMW adiponectin, and the HMW/total adiponectin ratio in bGH, GHA, and $\mathrm{Ghr}^{-1-}$ mice and their matched WT controls. Data are presented as mean \pm S.E.M. *Significant difference from WT at a given age as determined by ANOVA. (A, B, C, D, E and F) Total and
HMW adiponectin were measured side-by-side by ELISA in bGH (A and D), GHA (B and E), and $G_{h r}^{-1-}$ (C and F) mice. (G, H and I) The ratio of HMW adiponectin to total adiponectin was calculated for bGH (G), GHA (H), and $\mathrm{Ghr}^{-1-}$ (I) mice. 
Table 2 Significant Pearson correlations in bGH, GHA, and $\mathrm{Ghr}^{-1-}$ mice and their WT controls across lifespan

\section{Factors}

Total adiponectin $\times$ leptin

Total adiponectin $\times$ insulin Total adiponectin $\times$ total fat Total adiponectin $\times$ inguinal HMW adiponectin $\times$ leptin HMW adiponectin $\times$ total fat HMW adiponectin $\times$ inguinal $\mathrm{HMW} /$ total ratio $\times$ leptin $\mathrm{HMW} /$ total ratio $\times$ total fat

\begin{tabular}{c}
$r$ \\
\hline 0.507 \\
-0.175 \\
0.409 \\
0.563 \\
0.516 \\
0.426 \\
0.490 \\
0.239 \\
0.276
\end{tabular}

\begin{tabular}{l}
\hline $\boldsymbol{n}$ \\
\hline 190 \\
190 \\
183 \\
123 \\
190 \\
183 \\
123 \\
190 \\
183
\end{tabular}

\begin{tabular}{r}
\multicolumn{1}{c}{$\boldsymbol{P}$} \\
\hline$<0.001$ \\
0.013 \\
$<0.001$ \\
$<0.001$ \\
$<0.001$ \\
$<0.001$ \\
$<0.001$ \\
0.001 \\
$<0.001$
\end{tabular}

adiponectin in $\mathrm{Ghr}^{-/-}$mice was significantly increased compared with WT in 6-month-old mice but was not different in 1- and 2-year-old $\mathrm{Ghr}^{-/-}$mice (Fig. 1I). GHA mice had significantly increased HMW to total adiponectin ratios at 12 and 16.5 months of age but not at 3.2 or 6 months (Fig. 1H). bGH mice and matched WT controls had similar HMW/total adiponectin ratios throughout life (Fig. 1G).

\section{Correlational analysis}

Correlational analysis was performed on all bGH, GHA, and $\mathrm{Ghr}^{-1-}$ mice at all time points used in this study. Significant correlations are summarized in Table 2 . The analysis revealed a strong positive $(P \leq 0.001)$ correlation of total, HMW, and HMW/total adiponectin to circulating leptin concentrations. Total adiponectin was negatively correlated with circulating insulin concentrations. Correlation of total fat mass and individual depot masses with adiponectin levels revealed a strong positive $(P<0.001)$ correlation of total, HMW, and HMW/total adiponectin with total fat mass. Of note, total and HMW adiponectin were only significantly correlated with the mass of the inguinal fat pad $(P \leq 0.002)$ but not with the mass of the epididymal or mesenteric depots.

\section{Tissue adiponectin content}

Owing to the dramatic increase in circulating adiponectin and unique WAT distribution in $G h r^{-/-}$mice with a preferential enlargement of the inguinal (subcutaneous) depot, we measured the adiponectin protein content of three adipose depots (mesenteric, inguinal, and epididymal) in 6-month-old $G \mathrm{Gr}^{-/-}$mice to determine the source of the increased circulating adiponectin (Berryman et al. 2010). Several methods of normalization of these data were considered. When normalized to total protein content, there were no differences between genotypes in adiponectin content, although there was a depot difference in $G h r^{-/-}$mice. Specifically, mesenteric WAT had significantly decreased adiponectin content $(0.462 \pm 0.014 \mathrm{ng}$ adiponectin/ $\mu \mathrm{g}$ protein) when compared with epididymal and inguinal WAT (0.879 \pm 0.009 and $0.956 \pm 0.130 \mathrm{ng}$ adiponectin/ $\mu \mathrm{g}$ protein respectively) in $G h r^{-/-}$but not in WT mice. However, normalization to total protein content does not take into account the dramatic differences in depot size and body size (therefore blood volume). To account for these differences, we normalized tissue adiponectin content to depot weight/body weight. With this method of normalization, there was a significant decrease in adiponectin in the epididymal depot and a significant increase in the inguinal depot of $G h r^{-1-}$ mice when compared with WT littermate controls (Fig. 2).

\section{Adiponectin mRNA expression}

To further elucidate the potential source of changes in circulating adiponectin, adiponectin (Adipoq) expression was measured at a single time point for three models: 12-month-old $\mathrm{Ghr}^{-/-}$mice, 18-month-old GHA mice, and 2-month-old bGH mice and each group's WT controls. It is important to note that due to the age differences between the genotypes used in this series of experiments, expression data of a given mouse strain may be compared only to its corresponding WT controls and not between transgenic lines. Adiponectin expression did not differ from WT in epididymal or inguinal WAT in 12-month-old $\mathrm{Ghr}^{-/-}$, 18-month-old GHA, or 2-monthold bGH mice (data not shown). No significant effect of

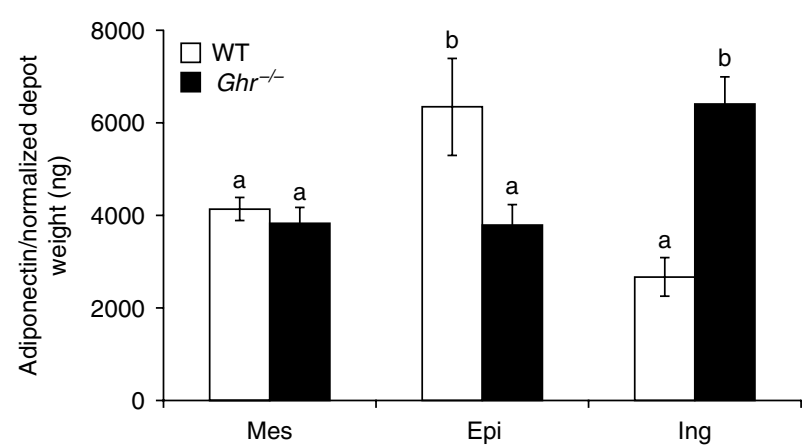

Figure 2

Tissue adiponectin content. Total adiponectin protein in mesenteric (Mes), epididymal (Epi), and inguinal (Ing) adipose tissue from 6-month-old $\mathrm{Ghr}^{-1-}$ and WT adipose tissue homogenates was measured by ELISA. Data are presented as mean \pm S.E.M. Within a genotype or depot, bars without a common letter are statistically different as determined by ANOVA. $n=9-10$. 


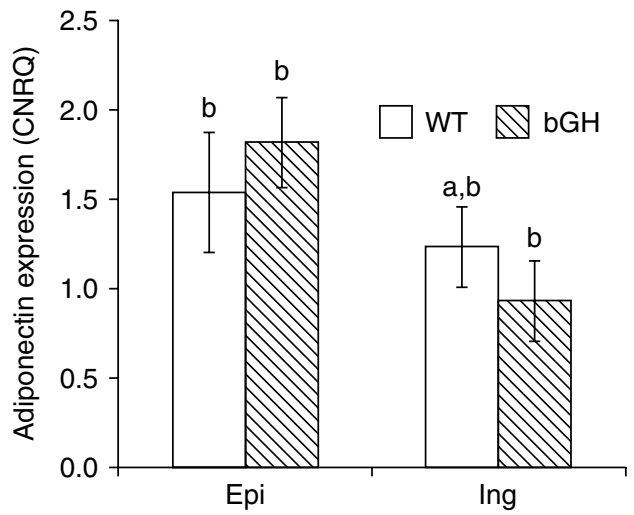

Figure 3

Expression of adiponectin in the epididymal (Epi) and inguinal (Ing) adipose depots of 2-month-old bGH mice and their WT littermate controls. Data are presented as mean \pm s.E.M. Within a genotype or depot, bars without a common letter are statistically different as determined by ANOVA and post hoc tests.

depot was found in GHA or $G h r^{-/-}$mice at the ages used. However, in bGH mice but in WT mice, inguinal WAT had significantly lower adiponectin expression than epididymal WAT (Fig. 3).

\section{Circulating HMW and total adiponectin in Ames, HiGH, and AOiGHD mice}

To confirm the results found in bGH, GHA, and $G h r^{-/-}$ mice, circulating total and HMW adiponectin was also measured at about 6 months of age in three additional models of modified GH signaling (Table 3): HiGH mice, which have a more modest elevation in GH/IGF1 axis than bGH mice; AOiGHD mice, which have an adult onset GH deficiency; and Ames dwarf mice, which lack GH as well as prolactin and $\mathrm{TSH}$. HiGH mice on a $\mathrm{HF}$ diet had a significant decrease in total and HMW adiponectin in circulation when compared with controls. However, there was no significant difference between AOiGHD mice and their controls. Ames dwarf mice showed a significant increase in total and HMW adiponectin when compared with phenotypically normal heterozygous controls. No difference in the HMW/total adiponectin ratio was observed for $\mathrm{HiGH}$, AOiGHD, or Ames dwarf mice compared with their respective controls.

\section{Circulating HMW and total adiponectin in $\mathrm{GH}-$ and IGF1-injected mice}

To determine the differential effects of GH and IGF1 and to examine the effects of acute GH administration, total and HMW adiponectin was measured in HF-fed mice injected with GH and/or IGF1 (Fig. 4). Mice injected with GH or IGF1 twice daily experienced a significant decrease in total adiponectin (Fig. 4A). Mice injected with both IGF1 and $\mathrm{GH}$ had circulating total adiponectin levels lower than those injected with either hormone alone, indicating an additive effect of GH and IGF1 (Fig. 4A). HMW adiponectin was significantly decreased in mice injected with GH compared with controls, but was not changed in mice injected with IGF1. Mice injected with both IGF1 and GH showed a decrease in HMW adiponectin similar to those injected with only GH. Regarding the ratio of HMW to total adiponectin, mice injected with GH or GH and IGF1 had significantly decreased ratios when compared with controls (Fig. 4B).

\section{Discussion}

Total adiponectin levels have been previously reported to be elevated in a few strains of mice with decreased $\mathrm{GH}$ action, while circulating total adiponectin has been reported to decrease in mice with increased $\mathrm{GH}$ action (Berryman et al. 2010). Our results confirm this. All mouse models of increased $\mathrm{GH}$ action, bGH, $\mathrm{HiGH}$, and GH-injected mice have significantly decreased total serum adiponectin levels when compared with their respective

Table 3 Total and HMW adiponectin in additional genotypes with altered GH action. $n=6$ for AOiGHD and HiGH mice, while $n=20$ for Ames dwarfs

\begin{tabular}{|c|c|c|c|}
\hline Model & Age (months) & Diet & Genotype \\
\hline Ames dwarf & 6.0 & Chow & $\begin{array}{l}\text { Control } \\
\text { Dwarf }\end{array}$ \\
\hline AOiGHD & 6.5 & $\mathrm{HF}$ & $\begin{array}{l}\text { Control } \\
\text { AOiGHD }\end{array}$ \\
\hline $\mathrm{HiGH}$ & 6.5 & $\mathrm{HF}$ & $\begin{array}{l}\text { Control } \\
\mathrm{HiGH}\end{array}$ \\
\hline
\end{tabular}

\begin{tabular}{c}
\hline Total $(\mathrm{ng} / \mathrm{ml})$ \\
\hline $8526 \pm 625$ \\
$20206 \pm 886^{a}$ \\
$32068 \pm 4383$ \\
$24535 \pm 2858$ \\
$26153 \pm 2286$ \\
$16686 \pm 578^{a}$
\end{tabular}

\begin{tabular}{l} 
HMW (ng/ml) \\
\hline $3150 \pm 530$ \\
$8446 \pm 520^{a}$ \\
$7906 \pm 638$ \\
$6538 \pm 720$ \\
$4495 \pm 143$ \\
$3259 \pm 405^{a}$
\end{tabular}

Ratio

$0.35 \pm 0.04$

$0.42 \pm 0.02$

$0.27 \pm 0.04$

$0.30 \pm 0.07$

$0.18+0.01$

$0.24 \pm 0.03$

aSignificant difference from controls determined via ANOVA.

http://joe.endocrinology-journals.org DOI: 10.1530/JOE-12-0505
(C) 2013 Society for Endocrinology Printed in Great Britain
Published by Bioscientifica Ltd. 

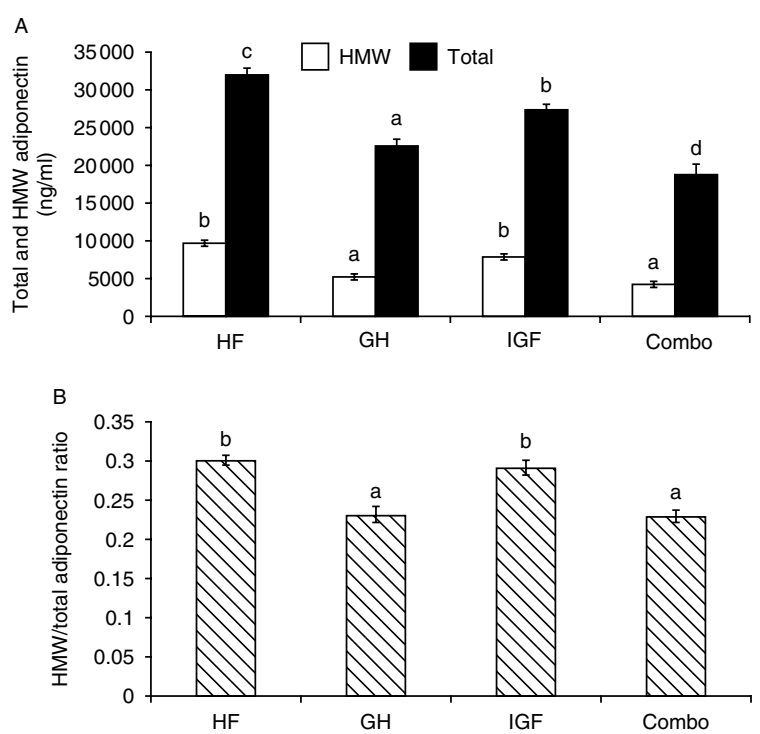

\section{Figure 4}

Circulating total adiponectin, HMW adiponectin, and the HMW/total adiponectin ratio in HF-fed mice injected with GH, IGF1, or a combination of GH and IGF1 (Combo). Data are presented as mean \pm s.E.M. Within a parameter, bars without a common letter are statistically different as determined by ANOVA. Circulating total adiponectin was measured by ELISA in mice fed a HF diet and injected with GH, IGF1, or a combination of the two (A). The ratio of HMW adiponectin to total adiponectin in mice fed a HF diet and injected with GH, IGF1, or both (B).

controls. By contrast, most mouse lines with decreased GH action (GHA, $\mathrm{Ghr}^{-/-}$, and Ames dwarf mice) have increased circulating total and HMW adiponectin. These findings fit nicely with data reported for individuals with acromegaly who have reduced serum adiponectin and Laron syndrome patients who have increased total and HMW adiponectin (Lam et al. 2004, Kanety et al. 2009). In our study, the only exception to this trend was with AOiGHD mice, which had no significant difference in total and HMW adiponectin levels despite reduced GH signaling. This exception may, in part, be explained by the late onset and relatively small reduction in circulating GH and/or by an effect of the HF diet. AOiGHD mice have a $60 \%$ reduction in GH signaling that occurs only after maturity is reached. By contrast, $G h r^{-/-}$, Ames dwarf, and GHA mice have greater reductions in GH signaling throughout life. Perhaps adiponectin in HF-fed AOiGHD remains unchanged due to the opposing effects of dietinduced obesity (DIO), which tends to reduce adiponectin, and reduced GH action, which tends to increase adiponectin (Louer et al. 2012). Thus, the partial reduction in GH might not be sufficient to relieve the inhibitory effect of DIO on adiponectin.
The bGH, GHA, and $G h r^{-/-}$mice have been previously shown to have significant differences in lifespan and adiposity (Coschigano et al. 2000, 2003, Bartke 2003, Magon 2009, Palmer et al. 2009, Berryman et al. 2010). Additionally, factors that affect and are affected by adipokine concentrations (e.g. adiposity and glucose tolerance) often vary with age (Arai et al. 2011, Schautz et al. 2012). Considering the variation in lifespan of these mice, comparing adipokine levels at a single time point is not appropriate, as a given chronological age may represent a different biological age in each genotype. For example, 1 year is nearing the end of a bGH mouse's lifespan, while it is only a quarter of a $\mathrm{Ghr}^{-/-}$mouse's lifespan and about half way through the lifespan of a WT mouse. Therefore, it might be expected that total and HMW adiponectin would vary with advancing age. Though it has been reported that adiposity increases throughout life in $\mathrm{Ghr}^{-/-}$and WT mice (Berryman et al. 2004, 2010), our data show that total adiponectin levels remain relatively constant in adult mice on a chow diet. Unlike total adiponectin, circulating levels of HMW adiponectin and the HMW/total adiponectin ratio varied with age. These data highlight the importance of careful age selection when designing an experiment investigating HMW adiponectin.

No previous studies on mice with altered GH action have differentiated between total and HMW forms of adiponectin. As different forms of adiponectin may influence its bioactivity and because these mice exhibit extreme differences in longevity, insulin sensitivity, and body composition, evaluating HMW adiponectin may contribute to defining the mechanisms responsible for the differences in longevity and insulin sensitivity in these mice (Coschigano et al. 2000, 2003, Berryman et al. 2004, 2011, Liu et al. 2004, Olsson et al. 2005). The HMW form of adiponectin is thought to be the most bioactive in terms of insulin sensitivity as decreases in HMW adiponectin are more closely correlated with HOMA-IR, obesity, metabolic syndrome, and insulin resistance than total adiponectin (Waki et al. 2003, Hara et al. 2006). The HMW/total adiponectin ratio has been suggested to be an appropriate way to report adiponectin complex distribution ( $\mathrm{O}^{\prime}$ Leary et al. 2007). Additionally, $d b / d b$ mice, which have severe insulin resistance, have similar total adiponectin levels to $d b /+$ littermates, yet have a dramatic decrease in specifically the HMW form, resulting in decreases in HMW/total adiponectin ratio. The current study shows that circulating HMW adiponectin follows nearly the same pattern as total adiponectin at most time points and does not provide additional insight into insulin sensitivity

Published by Bioscientifica Ltd 
or longevity. These data suggest that, at least in the context of altered GH action, HMW adiponectin and HMW/total adiponectin ratio may not be strongly linked to insulin sensitivity.

As IGF1 levels are generally reflective of GH levels and many of the effects of GH act via IGF1, it is often difficult to differentiate between the effects of GH and IGF1. To shed light on this matter, we measured circulating total and HMW adiponectin in mice injected with GH, IGF1, or both. Injection with GH significantly reduced circulating total adiponectin. Interestingly, this decrease in adiponectin is associated with an improvement in many metabolic parameters, as injection of the same dose of GH has previously been shown to decrease fat mass and liver triglycerides and improve glucose tolerance (List et al. 2009). Injection with IGF1 also significantly reduced the circulating total adiponectin, though not to the extent of GH injection. Thus, we hypothesize that the actions of GH on total adiponectin levels are at least partially dependent on IGF1 action, as IGF1 injection alone lowers circulating adiponectin. Injection with both GH and IGF1 induced a greater reduction in total adiponectin than either hormone alone, implying an additive effect of GH and IGF1 on total adiponectin. Injection with IGF1 did not change the circulating levels of HMW adiponectin or the HMW/total adiponectin ratio. These data show that while both GH and IGF1 affect total adiponectin, only GH modulates HMW adiponectin. Of note, all other mouse lines used in this study were transgenic or had natural mutations resulting in chronic alterations to GH activity. GH injections into WT mice show that an acute increase in GH action also negatively regulates circulating adiponectin levels.

The strong positive correlations between adiponectin and total fat mass suggest that these changes may be due to modulation of WAT mass by GH. As GH is lipolytic, mice with increased GH action tend to have lower WAT mass, while mice with decreased GH action have increased adipose mass (Berryman et al. 2011). Mice with low GH action show a healthy obese phenotype, escaping the negative health consequences of obesity. We hypothesize that this is through the healthy expansion of WAT without the inflammation that typically accompanies fat expansion. To support this, increased GH signaling has been associated with increased inflammation, while $G \mathrm{Gr}^{-/-}$mice have been shown to have lower levels of circulating inflammatory cytokines (Hattori 2009, Masternak et al. 2012). Likewise, inflammatory markers such as MCP1, IL6, and IL10 have been reported to increase with increased duration of
HF feeding and progression of DIO (Stanton et al. 2011). We propose that the often-reported reduction of adiponectin in WT HF-fed DIO mice may be due to the inflammation associated with DIO rather than simply the increase in adipose mass. This hypothesis could also explain some of the differential effects of a HF diet on adiponectin production, as the circulating adiponectin levels would depend on both the level of inflammation and the increase in adipose mass, which could vary greatly between studies.

While it is often reported that mice with low levels of GH signaling have increased circulating adiponectin, the adipose depot responsible for the increased adiponectin is not known. As the $\mathrm{Ghr}^{-/-}$and GHA mice used in this study have a unique adipose distribution with a preferential enlargement of subcutaneous WAT and this depot is thought to have metabolically beneficial effects, it is possible that the increased adiponectin is simply due to the increased mass of the subcutaneous (inguinal) depot (Berryman et al. 2004). Additionally, the correlation of total and HMW adiponectin levels with inguinal adipose depot weights $(P \leq 0.001)$ imply that this depot may be contributing more to the differences in circulating adiponectin levels. One previous study has attempted to determine the origin of elevated adiponectin in mice with decreased GH signaling. Masternak et al. (2012) performed visceral fat removal surgeries on $\mathrm{Ghr}^{-/-}$and WT mice and found that circulating adiponectin was decreased after removal of epididymal and perinephric WAT in $G h r^{-/-}$but not in WT mice, implying that visceral WAT is a primary contributor to elevated circulating adiponectin in $\mathrm{Ghr}^{-/-}$mice. This study also found that tissue adiponectin protein content normalized to total protein content is higher in epididymal WAT than in inguinal WAT. However, we found no significant genotype or depot differences in tissue adiponectin content when normalized in this manner. As mentioned previously, normalization to total protein content does not take into consideration the differences in depot and body size. In order to compensate for these differences, the current study normalized data to depot/body weight. When normalized in this manner, adiponectin content was increased in the inguinal depot of $\mathrm{Ghr}^{-/-}$mice. While these results appear to be contradictory, the $G h r^{-/-}$mice used in the visceral fat removal study have a different genetic background (129Ola/BALB/c, C3H/C57) and, on this background, all depots, not just the inguinal fat pad, are enlarged (Panici et al. 2009). Thus, the observed difference in tissue adiponectin content could be due to different background strains. Of note, adiponectin

Published by Bioscientifica Ltd. 
protein content was not assessed in all fat depots in either study. It is possible that other fat pads, such as subscapular subcutaneous fat or brown fat, could contribute substantially to the adiponectin in circulation. Thus, it is difficult to make a strong conclusion without a more comprehensive assessment. Interestingly, measurement of mRNA expression of the adiponectin gene, Adipoq, revealed no genotype or depot differences in bGH, GHA, or $\mathrm{Ghr}^{-/-}$, except that bGH mice had significantly lower expression of Adipoq in inguinal WAT when compared with epididymal. These data suggest that adiponectin is not regulated at the level of mRNA, but rather another level of regulation (translational/posttranslational/ degradation) is likely responsible for the variation in circulating adiponectin levels.

While adiponectin has often been associated with increased longevity, this paper questions its importance in influencing longevity. Several models of extended longevity via alterations in the GH/IGF1 pathway have increased circulating adiponectin, including Snell dwarf, Ames dwarf, Dwarf Lit/Lit, Sma1, and $\mathrm{Ghr}^{-/-}$mice (Flurkey et al. 2001, Combs et al. 2003, Berryman et al. 2004, Wang et al. 2006, 2007, Arumugam et al. 2007, del Rincon et al. 2007, Alderman et al. 2009). Calorically restricted mice, which are also long-lived, show increased circulating adiponectin levels (McKee Alderman et al. 2010, Qiao et al. 2011). Additionally, mice expressing high levels of human adiponectin show increased longevity (Otabe et al. 2007). Links between high adiponectin levels and healthy human aging have also been reported (Arai et al. 2006, Bik et al. 2006, Atzmon et al. 2008). However, data from this study question this, as GHA mice have a normal lifespan (Coschigano et al. 2003) yet extremely high levels of circulating total and HMW adiponectin (Fig. 1B and E). These data in GHA mice demonstrate that elevated adiponectin alone is not sufficient to extend longevity in mice with reduced GH signaling. However, it should also be noted that GHA mice develop severe obesity and do not have any decrease in lifespan, indicating that the high circulating adiponectin in these mice may offer some protection from age- and obesity-associated pathologies that would normally affect obese mice.

In conclusion, the current study provides greater insight into the interplay of $\mathrm{GH}$ and adiponectin. The association of low GH with high adiponectin and vice versa is strengthened in this study by the measurement of adiponectin in an array of mouse strains and at varied ages. Interestingly, GH appears to modulate both total and HMW adiponectin, while IGF1 modulates only total adiponectin. The lack of consistent association of HMW adiponectin or HMW/total adiponectin ratio with insulin sensitivity sheds doubt on the relevance of these parameters as indicators of insulin sensitivity in the context of increased or decreased GH signaling. Additionally, data showing GHA mice have dramatically increased total and HMW adiponectin throughout life without extended longevity implies a need for further investigation of adiponectin's link with aging. Using this unique system in which obesity is dissociated from insulin resistance, the current study confirms a strong negative relationship between GH signaling and adiponectin levels but questions the role of HMW adiponectin in controlling insulin sensitivity or longevity in mice.

\section{Declaration of interest}

The authors declare that there is no conflict of interest that could be perceived as prejudicing the impartiality of the research reported.

\section{Funding}

This work was supported in part by the State of Ohio's Eminent Scholar Program that includes a gift from Milton and Lawrence Goll; by the AMVETS; by the Diabetes Institute at Ohio University; by NIH grants DK083729, DK088133 AG031736, and AG031465; by the Gates Millennium Scholars Program; by Fundacion Alfonso Martin Escudero; and by the Department of Veterans Affairs, Veterans Health Administration, Office of Research and Development Merit Award.

\section{Acknowledgements}

The authors express their appreciation to Aubree K Ziegler and Bailey Miles for their assistance in running ELISAs.

\section{References}

Alderman JM, Flurkey K, Brooks NL, Naik SB, Gutierrez JM, Srinivas U, Ziara KB, Jing L, Boysen G, Bronson R et al. 2009 Neuroendocrine inhibition of glucose production and resistance to cancer in dwarf mice. Experimental Gerontology 44 26-33. (doi:10.1016/j.exger.2008. 05.014)

Arai Y, Nakazawa S, Kojima T, Takayama M, Ebihara Y, Shimizu K-i, Yamamura K, Homma S, Osono Y, Gondo Y et al. 2006 High adiponectin concentration and its role for longevity in female centenarians. Geriatrics \& Gerontology International 6 32-39. (doi:10.1111/j.1447-0594.2006.00304.x)

Arai Y, Takayama M, Abe Y \& Hirose N 2011 Adipokines and aging. Journal of Atherosclerosis and Thrombosis 18 545-550. (doi:10.5551/ jat.7039)

Arita Y, Kihara S, Ouchi N, Takahashi M, Maeda K, Miyagawa J, Hotta K, Shimomura I, Nakamura T, Miyaoka K et al. 1999 Paradoxical decrease of an adipose-specific protein, adiponectin, in obesity. Biochemical and Biophysical Research Communications 257 79-83. (doi:10.1006/bbrc. 1999.0255)

Arumugam R, Fleenor D \& Freemark M 2007 Effects of lactogen resistance and GH deficiency on mouse metabolism: pancreatic hormones, http://joe.endocrinology-journals.org DOI: 10.1530/JOE-12-0505
(C) 2013 Society for Endocrinology Printed in Great Britain 
adipocytokines, and expression of adiponectin and insulin receptors. Endocrine 32 182-191. (doi:10.1007/s12020-007-9017-y)

Atzmon G, Pollin TI, Crandall J, Tanner K, Schechter CB, Scherer PE, Rincon M, Siegel G, Katz M, Lipton RB et al. 2008 Adiponectin levels and genotype: a potential regulator of life span in humans. Journals of Gerontology. Series A, Biological Sciences and Medical Sciences 63 447-453. (doi:10.1093/gerona/63.5.447)

Bartke A 2003 Can growth hormone (GH) accelerate aging? Evidence from GH-transgenic mice Neuroendocrinology 78 210-216. (doi:10.1159/ 000073704)

Berg AH, Combs TP, Du X, Brownlee M \& Scherer PE 2001 The adipocytesecreted protein Acrp30 enhances hepatic insulin action. Nature Medicine 7 947-953. (doi:10.1038/90992)

Berryman DE, List EO, Coschigano KT, Behar K, Kim JK \& Kopchick JJ 2004 Comparing adiposity profiles in three mouse models with altered GH signaling. Growth Hormone \& IGF Research 14 309-318. (doi:10.1016/j. ghir.2004.02.005)

Berryman DE, List EO, Palmer AJ, Chung MY, Wright-Piekarski J, Lubbers E, O'Connor P, Okada S \& Kopchick JJ 2010 Two-year body composition analyses of long-lived GHR null mice. Journals of Gerontology. Series A, Biological Sciences and Medical Sciences 65 31-40. (doi:10.1093/gerona/ glp175)

Berryman DE, List EO, Sackmann-Sala L, Lubbers E, Munn R \& Kopchick JJ 2011 Growth hormone and adipose tissue: beyond the adipocyte. Growth Hormone \& IGF Research 21 113-123. (doi:10.1016/j.ghir.2011. 03.002)

Bik W, Baranowska-Bik A, Wolinska-Witort E, Martynska L, Chmielowska M, Szybinska A, Broczek K \& Baranowska B 2006 The relationship between adiponectin levels and metabolic status in centenarian, early elderly, young and obese women. Neuro Endocrinology Letters 27 493-500.

Chen WY, White ME, Wagner TE \& Kopchick JJ 1991 Functional antagonism between endogenous mouse growth hormone (GH) and a GH analog results in dwarf transgenic mice. Endocrinology 129 14021408. (doi:10.1210/endo-129-3-1402)

Combs TP, Berg AH, Rajala MW, Klebanov S, Iyengar P, Jimenez-Chillaron JC, Patti ME, Klein SL, Weinstein RS \& Scherer PE 2003 Sexual differentiation, pregnancy, calorie restriction, and aging affect the adipocyte-specific secretory protein adiponectin. Diabetes 52 268-276. (doi:10.2337/ diabetes.52.2.268)

Coschigano KT, Clemmons D, Bellush LL \& Kopchick JJ 2000 Assessment of growth parameters and life span of GHR/BP gene-disrupted mice. Endocrinology 141 2608-2613. (doi:10.1210/en.141.7.2608)

Coschigano KT, Holland AN, Riders ME, List EO, Flyvbjerg A \& Kopchick JJ 2003 Deletion, but not antagonism, of the mouse growth hormone receptor results in severely decreased body weights, insulin, and insulin-like growth factor I levels and increased life span. Endocrinology 144 3799-3810. (doi:10.1210/en.2003-0374)

Ding J, List EO, Bower BD \& Kopchick JJ 2011 Differential effects of growth hormone versus insulin-like growth factor-I on the mouse plasma proteome. Endocrinology 152 3791-3802. (doi:10.1210/en.2011-1217)

Ebinuma H \& Matsuo M 2009 Protease-based ELISA for selective quantification of mouse high-molecular-weight adiponectin. Clinica Chimica Acta 401 181-183. (doi:10.1016/j.cca.2008.11.013)

von Eynatten M, Humpert PM, Bluemm A, Lepper PM, Hamann A, Allolio B, Nawroth PP, Bierhaus A \& Dugi KA 2008 High-molecular weight adiponectin is independently associated with the extent of coronary artery disease in men. Atherosclerosis 199 123-128. (doi:10.1016/j. atherosclerosis.2007.10.002)

Fisher FM, Trujillo ME, Hanif W, Barnett AH, McTernan PG, Scherer PE \& Kumar S 2005 Serum high molecular weight complex of adiponectin correlates better with glucose tolerance than total serum adiponectin in Indo-Asian males. Diabetologia 48 1084-1087. (doi:10.1007/s00125005-1758-7)

Flurkey K, Papaconstantinou J, Miller RA \& Harrison DE 2001 Lifespan extension and delayed immune and collagen aging in mutant mice with defects in growth hormone production. PNAS 98 6736-6741. (doi:10.1073/pnas.111158898)

Gahete MD, Cordoba-Chacon J, Anadumaka CV, Lin Q, Bruning JC, Kahn CR, Luque RM \& Kineman RD 2011 Elevated GH/IGF-I due to somatotrope-specific loss of both IGF-I and insulin receptors, alters glucose homeostasis and insulin sensitivity in a diet-dependent manner. Endocrinology 152 4825-4837. (doi:10.1210/en.2011-1447)

Hara K, Horikoshi M, Yamauchi T, Yago H, Miyazaki O, Ebinuma H, Imai Y, Nagai R \& Kadowaki T 2006 Measurement of the high-molecular weight form of adiponectin in plasma is useful for the prediction of insulin resistance and metabolic syndrome. Diabetes Care 29 1357-1362. (doi:10.2337/dc05-1801)

Hattori N 2009 Expression, regulation and biological actions of growth hormone $(\mathrm{GH})$ and ghrelin in the immune system. Growth Hormone \& IGF Research 19 187-197. (doi:10.1016/j.ghir.2008.12.001)

Kadowaki T, Yamauchi T, Kubota N, Hara K, Ueki K \& Tobe K 2006 Adiponectin and adiponectin receptors in insulin resistance, diabetes, and the metabolic syndrome. Journal of Clinical Investigation $\mathbf{1 1 6}$ 1784-1792. (doi:10.1172/JCI29126)

Kanety H, Hemi R, Ginsberg S, Pariente C, Yissachar E, Barhod E, Funahashi T \& Laron Z 2009 Total and high molecular weight adiponectin are elevated in patients with Laron syndrome despite marked obesity. European Journal of Endocrinology 161 837-844. (doi:10.1530/EJE-09-0419)

Kern PA, Di Gregorio GB, Lu T, Rassouli N \& Ranganathan G 2003 Adiponectin expression from human adipose tissue: relation to obesity, insulin resistance, and tumor necrosis factor- $\alpha$ expression. Diabetes $\mathbf{5 2}$ 1779-1785. (doi:10.2337/diabetes.52.7.1779)

Lam KS, Xu A, Tan KC, Wong LC, Tiu SC \& Tam S 2004 Serum adiponectin is reduced in acromegaly and normalized after correction of growth hormone excess. Journal of Clinical Endocrinology and Metabolism 89 5448-5453. (doi:10.1210/jc.2003-032023)

Lara-Castro C, Luo N, Wallace P, Klein RL \& Garvey WT 2006 Adiponectin multimeric complexes and the metabolic syndrome trait cluster. Diabetes 55 249-259. (doi:10.2337/diabetes.55.01.06.db05-1105)

Laron Z \& Kopchick JJ 2011 Laron Syndrome - From Man to Mouse: Lessons From Clinical and Experimental Experience. Berlin, London: Springer.

List EO 2010 Effects of GH and IGF-1 treatments on body composition, glucose metabolism and hepatic gene expression in obese/diabetic mice with nonalcoholic fatty liver disease. Growth Hormone \& IGF Research 20(Supplement 1) S74-S75. (doi:10.1016/S1096-6374(10)70195-7)

List EO, Palmer AJ, Berryman DE, Bower B, Kelder B \& Kopchick JJ 2009 Growth hormone improves body composition, fasting blood glucose, glucose tolerance and liver triacylglycerol in a mouse model of dietinduced obesity and type 2 diabetes. Diabetologia 52 1647-1655. (doi:10.1007/s00125-009-1402-z)

List EO, Sackmann-Sala L, Berryman DE, Funk K, Kelder B, Gosney ES, Okada S, Ding J, Cruz-Topete D \& Kopchick JJ 2011 Endocrine parameters and phenotypes of the growth hormone receptor gene disrupted $\left(\mathrm{GHR}^{-1-}\right)$ mouse. Endocrine Reviews 32 356-386. (doi:10.1210/er.2010-0009)

Liu JL, Coschigano KT, Robertson K, Lipsett M, Guo Y, Kopchick JJ, Kumar U \& Liu YL 2004 Disruption of growth hormone receptor gene causes diminished pancreatic islet size and increased insulin sensitivity in mice. American Journal of Physiology. Endocrinology and Metabolism 287 E405-E413. (doi:10.1152/ajpendo.00423.2003)

Louer CR, Furman BD, Huebner JL, Kraus VB, Olson SA \& Guilak F 2012 Diet-induced obesity significantly increases the severity of posttraumatic arthritis in mice. Arthritis and Rheumatism 64 3220-3230. (doi:10.1002/art.34533)

Luque RM, Lin Q, Cordoba-Chacon J, Subbaiah PV, Buch T, Waisman A, Vankelecom H \& Kineman RD 2011 Metabolic impact of adult-onset, isolated, growth hormone deficiency (AOiGHD) due to destruction of pituitary somatotropes. PLOS ONE 6 e15767. (doi:10.1371/journal. pone.0015767) 
Maeda K, Okubo K, Shimomura I, Funahashi T \& Matsuzawa Y 1996 cDNA cloning and expression of a novel adipose specific collagen-like factor, apM1 (AdiPose Most abundant Gene transcript 1). Biochemical and Biophysical Research Communications 221 286-289. (doi:10.1006/bbrc. 1996.0587)

Magon V 2009 Body composition and adipokine levels in growth hormone antagonist mice. In Health and Human Services, p 173. Athens: Ohio University. Dissertation for Master of Science submitted to Ohio University, Athens, OH, USA.

Masternak MM, Panici JA, Wang F, Wang Z \& Spong A 2010 The effects of growth hormone $(\mathrm{GH})$ treatment on $\mathrm{GH}$ and insulin/IGF-1 signaling in long-lived Ames dwarf mice. Journals of Gerontology. Series A, Biological Sciences and Medical Sciences 65 24-30. (doi:10.1093/gerona/glp172)

Masternak MM, Bartke A, Wang F, Spong A, Gesing A, Fang Y, Salmon AB, Hughes LF, Liberati T, Boparai R et al. 2012 Metabolic effects of intraabdominal fat in GHRKO mice. Aging Cell 11 73-81. (doi:10.1111/j. 1474-9726.2011.00763.x)

McKee Alderman J, DePetrillo MA, Gluesenkamp AM, Hartley AC, Verhoff SV, Zavodni KL \& Combs TP 2010 Calorie restriction and dwarf mice in gerontological research. Gerontology 56 404-409. (doi:10.1159/000235720)

Nilsson L, Binart N, Bohlooly YM, Bramnert M, Egecioglu E, Kindblom J, Kelly PA, Kopchick JJ, Ormandy CJ, Ling C et al. 2005 Prolactin and growth hormone regulate adiponectin secretion and receptor expression in adipose tissue. Biochemical and Biophysical Research Communications 331 1120-1126. (doi:10.1016/j.bbrc.2005.04.026)

O'Leary VB, Jorett AE, Marchetti CM, Gonzalez F, Phillips SA, Ciaraldi TP \& Kirwan JP 2007 Enhanced adiponectin multimer ratio and skeletal muscle adiponectin receptor expression following exercise training and diet in older insulin-resistant adults. American Journal of Physiology. Endocrinology and Metabolism 293 E421-E427. (doi:10.1152/ajpendo. 00123.2007)

Olsson B, Bohlooly YM, Fitzgerald SM, Frick F, Ljungberg A, Ahren B, Tornell J, Bergstrom G \& Oscarsson J 2005 Bovine growth hormone transgenic mice are resistant to diet-induced obesity but develop hyperphagia, dyslipidemia, and diabetes on a high-fat diet. Endocrinology 146 920-930. (doi:10.1210/en.2004-1232)

Otabe S, Yuan X, Fukutani T, Wada N, Hashinaga T, Nakayama H, Hirota N, Kojima M \& Yamada K 2007 Overexpression of human adiponectin in transgenic mice results in suppression of fat accumulation and prevention of premature death by high-calorie diet. American Journal of Physiology. Endocrinology and Metabolism 293 E210-E218. (doi:10.1152/ ajpendo.00645.2006)

Pajvani UB, Hawkins M, Combs TP, Rajala MW, Doebber T, Berger JP, Wagner JA, Wu M, Knopps A, Xiang AH et al. 2004 Complex distribution, not absolute amount of adiponectin, correlates with thiazolidinedione-mediated improvement in insulin sensitivity. Journal of Biological Chemistry 279 12152-12162. (doi:10.1074/jbc. M311113200)

Palmer AJ, Chung MY, List EO, Walker J, Okada S, Kopchick JJ \& Berryman DE 2009 Age-related changes in body composition of bovine growth hormone transgenic mice. Endocrinology 150 1353-1360. (doi:10.1210/en.2008-1199)

Panici JA, Wang F, Bonkowski MS, Spong A, Bartke A, Pawlikowska L, Kwok PY \& Masternak MM 2009 Is altered expression of hepatic insulin-related genes in growth hormone receptor knockout mice due to GH resistance or a difference in biological life spans? Journals of Gerontology. Series A, Biological Sciences and Medical Sciences 64 1126-1133. (doi:10.1093/gerona/glp111)
Qiao L, Lee B, Kinney B, Yoo HS \& Shao J 2011 Energy intake and adiponectin gene expression. American Journal of Physiology. Endocrinology and Metabolism 300 E809-E816. (doi:10.1152/ajpendo. 00004.2011)

del Rincon JP, Iida K, Gaylinn BD, McCurdy CE, Leitner JW, Barbour LA Kopchick JJ, Friedman JE, Draznin B \& Thorner MO 2007 Growth hormone regulation of $\mathrm{p} 85 \alpha$ expression and phosphoinositide 3-kinase activity in adipose tissue: mechanism for growth hormone-mediated insulin resistance. Diabetes 56 1638-1646. (doi:10.2337/db06-0299)

Sackmann-Sala L, Berryman DE, Lubbers ER, Vesel CB, Troike KM, List EO, Munn RD, Ikeno Y \& Kopchick JJ 2012a Decreased insulin sensitivity and increased oxidative damage in wasting adipose tissue depots of wild-type mice. Age 34 1225-1237. (doi:10.1007/s11357-011-9304-7)

Sackmann-Sala L, Berryman DE, Munn RD, Lubbers ER \& Kopchick JJ $2012 b$ Heterogeneity among white adipose tissue depots in male C57BL/6J mice. Obesity 20 101-111. (doi:10.1038/oby.2011.235)

Schautz B, Later W, Heller M, Peters A, Muller MJ \& Bosy-Westphal A 2012 Impact of age on leptin and adiponectin independent of adiposity. British Journal of Nutrition 108 363-370. (doi:10.1017/ S0007114511005605)

Stanton MC, Chen SC, Jackson JV, Rojas-Triana A, Kinsley D, Cui L, Fine JS, Greenfeder S, Bober LA \& Jenh CH 2011 Inflammatory signals shift from adipose to liver during high fat feeding and influence the development of steatohepatitis in mice. Journal of Inflammation $\mathbf{8} 8$. (doi:10.1186/1476-9255-8-8)

Trujillo ME \& Scherer PE 2006 Adipose tissue-derived factors: impact on health and disease. Endocrine Reviews 27 762-778. (doi:10.1210/ er.2006-0033)

Waki H, Yamauchi T, Kamon J, Ito Y, Uchida S, Kita S, Hara K, Hada Y, Vasseur F, Froguel P et al. 2003 Impaired multimerization of human adiponectin mutants associated with diabetes. Molecular structure and multimer formation of adiponectin. Journal of Biological Chemistry $\mathbf{2 7 8}$ 40352-40363. (doi:10.1074/jbc.M300365200)

Wang, X 2012 Verifying the Deletion of Growth Hormone Receptor Using a Quantitative Polymerase Chain Reaction at the mRNA Level in Tissue-Specific GHR-/- Mice Dissertation for Master of Science submitted to Academic department, School of Applied Health Sciences and Wellness, College of Health Sciences and Professions, Ohio University, Athens, OH, USA.

Wang Z, Al-Regaiey KA, Masternak MM \& Bartke A 2006 Adipocytokines and lipid levels in Ames dwarf and calorie-restricted mice. Journals of Gerontology. Series A, Biological Sciences and Medical Sciences 61 323-331. (doi:10.1093/gerona/61.4.323)

Wang Z, Masternak MM, Al-Regaiey KA \& Bartke A 2007 Adipocytokines and the regulation of lipid metabolism in growth hormone transgenic and calorie-restricted mice. Endocrinology 148 2845-2853. (doi:10.1210/en.2006-1313)

Wang Y, Lam KS, Yau MH \& Xu A 2008 Post-translational modifications of adiponectin: mechanisms and functional implications. Biochemical Journal 409 623-633. (doi:10.1042/BJ20071492)

Yamauchi T, Kamon J, Waki H, Terauchi Y, Kubota N, Hara K, Mori Y, Ide T, Murakami K, Tsuboyama-Kasaoka N et al. 2001 The fat-derived hormone adiponectin reverses insulin resistance associated with both lipoatrophy and obesity. Nature Medicine 7 941-946. (doi:10.1038/ 90984)

Zhou Y, Xu BC, Maheshwari HG, He L, Reed M, Lozykowski M, Okada S, Cataldo L, Coschigamo K, Wagner TE et al. 1997 A mammalian model for Laron syndrome produced by targeted disruption of the mouse growth hormone receptor/binding protein gene (the Laron mouse). PNAS 94 13215-13220. (doi:10.1073/pnas.94.24.13215)

Received in final form 5 December 2012

Accepted 21 December 2012

Accepted Preprint published online 21 December 2012 http://joe.endocrinology-journals.org DOI: 10.1530/JOE-12-0505
() 2013 Society for Endocrinology Printed in Great Britain 